\title{
Zezwierzęcenie świata ludzi. Nosorożec Eugène’a Ionesco
}

Nieco zapomniana obecnie sztuka Eugène'a Ionesco Rhinocéros (Nosorożec), napisana przez autora i wydana w 1959 roku $^{1}$, była często rozważana w kontekście czynionych przez autora odniesień do faszyzmu. Ale należy się zastanowić, czy tylko te, bardzo konkretne odwołania autor miał na uwadze? Warto też zasygnalizować, że nawet widziany w tym „okolicznościowym” aspekcie utwór Ionesco ukazuje swą ponadczasowość, zwłaszcza gdy zważymy, że faszystowskie rodem postawy nie zanikły w dzisiejszym świecie, a i metody narzucania tych postaw masom (lub środowiskom czy grupom) pozostały te same.

Dostrzegamy również ponadczasowość wymowy tej sztuki jako utworu, ukazującego dramatyczną, pogłębiającą się samotność człowieka jako indywiduum, jego wyobcowanie i lęki narastające pod wpływem otoczenia. I nawet jeśli ten aspekt utworu wydaje się nam obecnie mało nowatorski, choćby z racji obranego przez autora alegorycznego ujęcia, a także ze względu na wyraźne i jednoznaczne moralistyczne przesłanie, to jednak warto poświęcić Nosorożcowi nieco więcej uwagi.

Sztuka Ionesco jest także - a może nawet przede wszystkim - wymownym przykładem relacji: jednostka - społeczeństwo masowe, relacji szczególnie aktualnej w XX wieku (faszyzm, komunizm, socjalizm), ale obecnej także i dziś, dodatkowo w różnych, nawet obyczajowych, przejawach. I choć relacja ta objawia się w nowych konfiguracjach, z pozoru mniej groźnych, to jednak ciągle ukazuje swoje drapieżne oblicze i negatywne konsekwencje w życiu społeczeństw. Można zaryzykować twierdzenie, że nawet najbardziej z pozoru szlachetne ideologie także obecnie prowadzą do takiego „zezwierzęcenia” ogółu, jakie ukazał w Nosorożcu Ionesco.

Gdy mowa o postaciach Ionesco, mających wiele cech nietypowych, albo też nieludzkich, jak w tym przypadku ludzie przemieniający się bez większych kłopotów w nosorożce, gdy mamy na uwadze rozmnażające i powiększające się, ukazane w dramatach tego autora przedmioty i ciała (zjawisko określane mianem: „proliferacja”), jak na przykład jajka w Przyszłości w jaju, grzyby w Amadeuszu,

${ }^{*}$ Dr nauk humanistycznych w zakresie literaturoznawstwa, na podstawie rozprawy pisanej w Katedrze Dramatu i Teatru Uniwersytetu Łódzkiego; adres e-mail: quiproquo71@interia.pl

${ }^{1}$ E. Ionesco, Rhinocéros, piece en trois actes et quatre tableaux, Gallimard, Paris 1959. 
krzesła w Krzesłach, rosnący trup w Amadeuszu ${ }^{2}$, to przypomina się, że o takim świecie pisze autor w Notes et contre-notes: „Żadna granica nie może dla mnie oddzielać rzeczywistego od nierzeczywistego, prawdziwego od fałszywego"3.

Takie przeobrażenia można traktować rozmaicie, między innymi jako symbole ludzkich stanów psychicznych, rozmaitych postaw wobec życia, najczęściej szyderczo wydrwionych przez Ionesco. Jeśli wobec takich dziwacznych metamorfoz zostaje postawiony bohater, reprezentujący wyższe wartości ludzkie lub przynajmniej poszukujący tych wartości w świecie zdehumanizowanym (jak Bérenger w Nosorożcu), służy to pogłębieniu jego samotności, obcości, lęków w rzeczywistości, pozornie nierzeczywistej i nieprawdziwej, w istocie zaś dostępnej ludzkiemu doświadczeniu, lecz celowo, dla uwypuklenia jej grozy, groteskowo zdeformowanej.

Podobnie, dość często, występują w rozbudowanych w utworach dramatycznych Eugène'a Ionesco didaskaliach realistyczne informacje o świecie przedstawionym, jednak w trakcie rozwoju zdarzeń zaczyna dominować ich znaczenie symboliczne ${ }^{4}$. Tak na przykład dzieje się z różnymi miejscami akcji, opisanymi bardzo szczegółowo, wręcz detalicznie, na początku każdego z czterech obrazów Nosorożca ${ }^{5}$. Obserwujemy to również w Mordercy nie do wynajęcia (utworze znanym też pod innym tytułem: Morderca bez poborów $w^{6}$.

W obydwu sztukach głównym bohaterem jest „zwyczajny człowiek”, Bérenger, postać traktowana niekiedy jako porte-parole autora. Występuje on również $\mathrm{w}$ dwóch powstałych niedługo potem dramatach Ionesco: Pieszo w powietrzu oraz Król umiera, czyli Ceremonie ${ }^{7}$. Niektórzy krytycy akcentują jednakże odmienność poetyki i wymowy Nosorożca oraz Mordercy nie do wynajęcia, traktując te utwory na przykład jako alegoryczne przypowieści na temat Zła i Społeczeństwa ${ }^{8}$.

${ }^{2}$ Jan Kosiński pisze: „Ogromna większość sztuk [Ionesco - przyp. A. W.] da się sprowadzić do tego prostego schematu mechanicznego narastania i zwielokrotniania". Badacz ma tu na uwadze także Nosorożca (tenże, „Theatrum” Ionesco, „Dialog” 1963, nr 3, s. 97-98).

${ }^{3}$ Podaję za A. Brillant-Annequin, Teatr absurdu: narodziny współczesnej estetyki. Na przykładzie dramaturgii Ionesco i Becketta, tłum. M. Sugiera, „Ruch Literacki” 1995, z. 4, s. 479.

${ }^{4}$ Akcentuje ten aspekt A. Brillant-Annequin, tamże, s. 480.

${ }^{5}$ E. Ionesco, Teatr, oprac. i przedmowa M. Piwińska, t. II, Państwowy Instytut Wydawniczy, Warszawa 1967, s. 98-211.

${ }^{6}$ Pod takim tytułem sztuka ta w przekładzie polskim została opublikowana w: „Nowa Kultura", 1961, nr 19. Morderca nie do wynajęcia natomiast to tytuł przekładu w zbiorze: E. Ionesco, Teatr, t. II.

${ }^{7}$ Zwłaszcza w ostatniej z wymienionych tu sztuk bohater ma znacznie więcej cech Jedermanna niż w poprzednich utworach; zob. J. Błoński, Od „Łysej śpiewaczki” do Bérengera, „Dialog” 1963, nr 3, s. 101-102. Zarówno jednak Błoński (tamże), jak i krytycy francuscy, np. Gilles Sandier czy Robert Kanters widzą w postaci Bérengera również samego autora - Ionesco (zob. „Król umiera” w opinii krytyków, w dziale Kronika, „Dialog” 1963, nr 3, s. 148).

${ }^{8}$ Tak to traktuje np. Gilles Sandier, notabene odnotowując, że Nosorożec i Morderca... niestety, oddaliły odbiorców od Eysej śpiewaczki i od Krzeseł, od lęku, u źródeł którego tkwiło zdumienie stopniowym rozpadem czy mglistością rzeczy (,Król umiera” w opinii krytyków, s. 148). 
Nie tylko krytycy francuscy (jak Gilles Sandier czy Robert Kanters), lecz również niemiecki autor sztuk zaliczanych do teatru absurdu i krytyk w jednej osobie, Wolfgang Hildesheimer, podkreślił inność Nosorożca na tle dwudziestowiecznego dramatu absurdu. W jego wypowiedzi znajdziemy notabene wiele interesujących polemicznych odniesień do kontrowersyjnych poglądów wygłoszonych podczas dyskusji przeprowadzonej w trakcie X Międzynarodowego Tygodnia Teatrów Studenckich w Erlangen w 1960 roku, na temat: teatr absurdalny a teatr epicki (w znaczeniu tradycyjny, realistyczny) ${ }^{\text {. }}$

Hildesheimer uważa, że w dorobku teatru absurdalnego znaleźć można niejedną sztukę, która stała się popularna. Jednak jego zdaniem, fakt tej popularności nie ma nic wspólnego z ich absurdalnością. Podaje jako przykład sztukę Nosorożec Ionesco.

Owszem, zawiera ona w swych pysznych nieraz dialogach elementy absurdu, ale poza tym autor posłużył się w niej środkami zwyczajnej paraboli. [...] Również metamorfoza nie jest elementem absurdu - raczej już baśniowej gry. Mamy tu więc do czynienia z osobliwym produktem koncesji. Mówi się często: siła Ionesco polega na tym, że banalną sytuację wyjściową potrafi on potęgować do absurdu. Cóż, podobny chwyt zastosował on również w Nosorożcu - w każdej z postaci tej sztuki tkwi od początku mały nosorożec ${ }^{10}$.

Hildesheimer nie sądzi jednak, by na tym polegała siła Ionesco, i podaje przykład arcydzieła dramatu dwudziestego stulecia, najlepszej jego sztuki: Krzesła, która od początku rozgrywa się na obszarze fantastyczności, a nawet surrealizmu, a przy tym otwiera widoki na pewne aspekty świata wewnętrznego. Hildesheimer wyraża przeto następującą opinię:

Nie można działać jak Ionesco w Nosorożcu, na dwóch różnych płaszczyznach: z jednej strony na płaszczyźnie tradycyjnej paraboli, która przez wszystkie akty przygotowuje catharsis, z drugiej - na płaszczyźnie parabolicznej treści teatru absurdalnego, który całkowicie odrzuca catharsis ${ }^{11}$.

Robert Kanters, recenzując prapremierę sztuki Król umiera..., z zadowoleniem wita powrót motywów i ujęć bardziej charakterystycznych dla teatru absurdu w wydaniu Ionesco, rewindykację tego, co zdawało się, autor skazał na wygnanie. Metaforycznie ujmuje to w zdaniu (w przekładzie polskim): „Śpiewaczka odzyskała swój głos i odrosły jej włosy” (tamże).

${ }^{9} \mathrm{~W}$ festiwalu wzięli udział aktorzy i krytycy teatralni z ówczesnego bloku państw socjalistycznych oraz z Zachodu (stąd burzliwość dyskusji).

${ }^{10}$ Problemy teatru absurdalnego (w dziale Kronika), „Dialog” 1961, nr 2, s. 144-148. Znajdujemy tu streszczenie wypowiedzi Wolfganga Hildesheimera, wygłoszonej na festiwalu, a właściwie skrótowo ujęte tezy jego referatu w przekładzie polskim według niemieckiego miesięcznika „Akzente” 1960, nr 12.

${ }^{11}$ Tamże, s. 148. 
Nie ma w niniejszym artykule miejsca na polemikę z poglądami niemieckiego autora, zwłaszcza że i on uważa, iż niemoc i wątpliwość, obcość świata - to sens i tendencja każdej sztuki absurdalnej, które przyczyniają się zarazem do sprecyzowania i uświadomienia sytuacji człowieka, a to przecież znajdujemy w rozpatrywanej tu sztuce Ionesco. Chodzi raczej o to, co podkreślali również inni krytycy, dostrzegający odmienność Nosorożca od innych dramatów tego autora, nie wyciągając $\mathrm{z}$ tej obserwacji tak krańcowych wniosków. Teatr absurdalny jest parabolą o obcości człowieka w świecie, tyle że parabolą wielokrotnie posługującą się alegorią nieskonwencjalizowaną, niejasną, tajemniczą, dającą się rozmaicie interpretować. Parabola zawarta w Nosorożcu wydaje się zaś jaśniejsza, bardziej zrozumiała w odbiorze, a sztuka - silniej związana z rzeczywistością społeczno-polityczną niż inne utwory pisarza, posiadające bardziej abstrakcyjne odniesienia do pozascenicznego świata.

Również polski krytyk, Jan Kosiński, sygnalizował odmienność tej sztuki Ionesco o zwielokrotnionej przemianie ludzi w gruboskórne zwierzęta. Przypuszczał, że niektórym odbiorcom mogło się nawet wydawać, że po Nosorożcu nastąpi przemiana dramaturgii Ionesco w kierunku teatru bardziej zrozumiałego dla widza:

Mógł ktoś może sądzić, że sztuki coraz bardziej „normalne”, coraz mniej „,awangardowe", że sukces na scenach oficjalnych zobowiązuje do kontynuacji, a sam Nosorożec wydaje się zwłaszcza w dalszych scenach ucieczka od tej „nie zweryfikowanej" magmy dramatycznej stającej się na oczach widza, z jakiej były sztuki poprzednie, w opowiadanie „po bożemu” językiem mniej więcej „normalnej" dramaturgii, jakiejś mniej czy bardziej absurdalnej historii z sensem satyryczno-alegorycznym ${ }^{12}$.

Kosiński jednak (wypowiadający się kilka lat później), choć pisze:

W Nosorożcu, jak wszystkim wiadomo, najpierw pojawia się nosorożec, potem drugi, potem wszyscy po kolei zamieniają się w nosorożce - nosorogacizna ogarnia całą ludzkość - Bérenger zostaje sam, to jednak z całą mocą podkreśla wierność pisarza własnej palecie środków,

to zaznacza, że sukcesywna dekompozycja świata przedstawionego tu i w kilku innych sztukach Ionesco (należących z całą pewnością do dramatu absurdu) została zastosowana $\mathrm{w}$ celu podkreślenia tragicznej samotności bohatera ${ }^{13}$.

Krytyk przypomniał również, że pewnego rodzaju odmienność Nosorożca mogła wynikać także z tego, że ta sztuka dramatyczna była transpozycją noweli,

\footnotetext{
12 J. Kosiński, dz. cyt., s. 96.

${ }^{13}$ Tamże, s. 96-98.
} 
a więc swoistą estetyczno-literacką hybrydą, w obrębie której znalazły też swój wyraz prawa innego gatunku ${ }^{14}$.

Lesław Eustachiewicz określa alegorię występującą w Nosorożcu jako „,po wolteriańsku klarowną refleksyjnie i moralistycznie"15.

Na szczególne związki dwóch wcześniej wymienionych sztuk Eugène’a Ionesco z problematyką polityczną, a nawet na zwrot, jaki się w nich dokonał, zwraca uwagę Jan Błoński (także, jak Jan Kosiński, pod wpływem refleksji wywołanych nowymi dramatami z postacią Bérengera, to jest Pieszo w powietrzu oraz Król umiera, czyli Ceremonie):

Bérenger ma sporo cech Jedermanna, jest każdym z nas, ale zarazem samym pisarzem, dobrym gadułą, wrażliwym i niezdecydowanym, nękanym strapieniami świata, w którym przyszło mu żyć. Punktem zwrotnym był Morderca bez poborów: i tam, i w Nosorożcu odsłoniła się, jeżeli tak można powiedzieć, polityczna strona świata Ionesco. [...] Jakkolwiek by było, to nieśmiałe i melancholijne zaangażowanie, ta częściowa [...] i trochę wymuszona racjonalizacja wewnętrznego niepokoju wpłynęła decydująco na formę dramatyczną pisarza: sztuki wydłużyły się, sytuacje nabrały (względnej) jednoznaczności, wizyjność nabrzmiała alegoriami ${ }^{16}$.

Tadeusz Nyczek zaś, porównując sztuki Vaclava Havla i Sławomira Mrożka z dramatami innych reprezentantów teatru absurdu, akcentuje wyraźny związek z pozateatralną rzeczywistością, widoczny właśnie w Nosorożcu ${ }^{17}$.

Widzimy, że opiniom formułowanym przez krytyków wobec dwóch pierwszych sztuk z Bérengerem, jako bohaterem, a podkreślającym związki tych utworów z zagadnieniami społeczno-politycznymi, nie przeszkadzała niechęć Ionesco do obarczania dramaturgii zadaniami ideologiczno-politycznymi, a nawet otwarta polemika z teatrem zaangażowanym Bertolda Brechta. (Warto tu przytoczyć znamienne słowa, zanotowane w Notes et contre-notes: „Nie lubię Brechta, właśnie dlatego, że jest dydaktykiem, ideologiem"18). Rzecz bowiem w tym, że u Ionesco zagadnienia ideologii i polityki pojawiały się znacznie rzadziej, można rzec - wyjątkowo, a ponadto w formie, umożliwiającej bardziej wieloznaczną interpretację jego dramatycznych tekstów.

14 Tamże, s. 96.

${ }^{15}$ L. Eustachiewicz, Dramaturgia współczesna 1945-1980, Warszawa 1985, s. 28.

${ }^{16}$ J. Błoński, Od „Łysej śpiewaczki” do Bérengera, s. 101.

${ }^{17}$ Badacz pisze m.in.: „,Wypełnione żywą treścią socjalistycznego absurdu sztuki obu Słowian okazują się znacznie mocniej zakotwiczone w rzeczywistości niż przeważnie całkiem abstrakcyjne (poza Nosorożcem Ionesco i Wizyta starszej pani Dürenmatta) sztuki zachodnich absurdalistów" (T. Nyczek, Havel: u szczytu schodów, „Dialog” 1990, nr 11, s. 90).

${ }^{18}$ Cyt. za: A. Brillant-Annequin, dz. cyt., s. 481. 
Rozważania z kręgu dehumanizacji w sztuce, w tym - dehumanizacji w sztuce teatru, będącej swoistym antidotum na dehumanizację w życiu, odnaleźć można również w refleksjach francuskiej badaczki, Anick Brillant-Annequin, która sporo miejsca poświęca cechom warsztatowym (zwłaszcza) i wymowie Nosorożca, choć zajmuje ją przede wszystkim szczegółowe porównanie cech dramaturgii Samuela Becketta i Eugène’a Ionesco (zarówno analogii, jak i pewnych różnic) ${ }^{19}$.

W Nosorożcu Ionesco jesteśmy obserwatorami „akcji bezpośredniej”, znamiennej dla dramatu absurdu, ukazującego wielokrotnie relację: jednostka - społeczeństwo masowe ${ }^{20}$. Różnica polega na tym, że ta „akcja” została ujęta za pomocą alegorii zwierzęcej, w groteskowy sposób. Nie przeprowadzają jej więc posiadający już siłę i władzę pospolici członkowie masy, dopiero liczący na wzrost swego znaczenia w tworzącej się gromadzie. Przeprowadza ją w miasteczku za pomocą coraz większej ilości (spowodowanej „zaraźliwym” upodobnieniem do niego) nosorożców - brzydki, prymitywny, silny, tratujący otoczenie, ryczący groźnie Nosorożec, który pojawia się nagle, nie wiadomo skąd.

Z początku mieszkańcy są bardzo oburzeni panoszeniem się zwierzęcia, głośno oburzają się, protestują; wydaje się nawet, że możliwe będzie danie odporu tej brutalnej sile. Towarzyszy temu jednak wszechogarniający strach. Po niedługim czasie okazuje się, że brutalna „akcja bezpośrednia” odnosi swój skutek. Następują kolejne przemiany kolejnych postaci, zezwierzęcenie zatacza coraz szersze kręgi. W wyniku „akcji bezpośredniej”, wywołanej rykami, cwałowaniem i popisami siły grasującego w miasteczku ciężkiego, gruboskórnego zwierza, ludzie „zmieniają skórę”, stopniowo przystosowują się do sytuacji, zaczynają tworzyć tłum podobnych mu nosorożców.

Sprzyja temu karykaturalnie przedstawiona przez Ionesco w dramacie pustka różnorodnych relacji międzyludzkich. Nie zostają oszczędzone związki małżeńskie (z czym notabene spotykamy się często w utworach tego pisarza), na przykład pozorne więzi Bérengera i Daisy; pozorne okazują się też rozmaite więzi koleżeńskie i sąsiedzkie, a nawet dotąd - przyjacielskie. Czy to parze małżonków, czy parze przyjaciół, czy panu i słudze trudno nawiązać prawdziwie bliskie re-

${ }^{19}$ Tamże, s. 475-494.

${ }^{20}$ Odnosząc się do metody „akcji bezpośredniej” jako usankcjonowanego w XX w. sposobu rozwiązywania różnorodnych konfliktów, warto tu przytoczyć znamienne spostrzeżenie hiszpańskiego filozofa i eseisty José Ortegi y Gasseta, które rzuca światło na specyfikę tego fenomenu: „Rzeczą pożałowania godną jest to, że kondycja ludzka zmusza nas co jakiś czas do uciekania się do tego rodzaju gwałtów, trudno jednak zaprzeczyć, że jest to wyraz najwyższego hołdu dla rozumu i sprawiedliwości. Bo przecież tego typu przemoc nie jest niczym innym jak powstaniem rozumu przeciwko sobie samemu. Siła staje się faktycznie «ultima ratio» [...]. Obecnie widać to aż za dobrze, bo «bezpośrednia racja» jest odwróceniem porządku i proklamacją gwałtu jako «prima ratio», a dokładniej rzecz biorąc, jako jedynej racji [...]. To Magna Charta barbarzyństwa" (J. Ortega y Gasset, Bunt mas i inne pisma socjologiczne, przeł. P. Niklewicz i H. Woźniakowski, wstęp J. Szacki, Państwowe Wydawnictwo Naukowe, Warszawa 1982, s. 74). 
lacje (przyjaźń okazywana przez Bérengera Janowi nie uchroni tegoż Jana przed przemianą w nosorożca). Należy również zwrócić uwagę na powierzchniowość, labilność dotąd panujących w ukazanym świecie wartości, w tym - wartości moralnych, ideowych i społecznych. Brak autentycznych więzi, stałych kryteriów etycznych, godnych zaufania wartości społecznych sprzyja dość łatwej w końcu i przebiegającej bez większych oporów powszechnej metamorfozie.

Tylko początkowe przeobrażenia budzą zdziwienie (na przykład przemiana pana Wołowiny), późniejsze, coraz bardziej masowe, są rozmaicie „usprawiedliwiane" i tłumaczone (metamorfoza żony pana Wołowiny ma być godnym uznania przejawem miłości do męża). Masa, dotąd bezkształtna, otrzymuje jednolitość - zarówno zewnętrzną, jak i wewnętrzną. Świat otaczający Bérengera w wyniku „akcji bezpośredniej” otrzymał kierunek, a członkowie masy, ludzie-zwierzęta - jedyną słuszną ich zdaniem rację istnienia i podobny kształt.

Rozszerzaniu się nosorogacizny sprzyja również „tragedia języka”. Pisze na ten temat Aneck Brillant-Annequin, podkreślając obecne w sztukach Ionesco rozbicie aktu wypowiadania, a nawet samego wypowiadającego, który przestaje postrzegać własne ciało jako całość, odrębną od otoczenia. Odnosi to również do postaci z Nosorożca, które:

przejmują z ust do ust repliki; te kolektywne repetycje dowodzą „rozpuszczenia się" indywidualnego ,ja” w zbiorowym, jego rozpadu na drobne fragmenty. Ciało, nie czując własnej jedności i granic, zostało skazane na przemianę w zwierzę, a jego język na przejście w ryk. Lecz nadal istnieje potrzeba ekspresji, co umożliwia komunikację, lecz wyłącznie na zwierzęcy sposób. Krzyki, odgłosy, onomatopeje to przecież czysty wyraz emocji, język ciała ${ }^{21}$.

Potwierdza się tu słuszność opinii Jana Błońskiego na temat wszechwładzy stereotypu (nie tylko językowego) u Ionesco, opinii mającej swe źródło w przeprowadzonej przez polskiego badacza obserwacji języka postaci scenicznych autora:

[...] słowa przestały cokolwiek znaczyć, zatarta została, właśnie za sprawą wyobcowanego i zużytego języka - wszelka możliwość porozumienia: ludzie nie mówią, ale „są mówieni” przez wszechogarniający frazes. Ionesco nieraz komentował twórcze olśnienie, które umożliwiło napisanie „tragedii języka”, jak lubił nazywać Łysa śpiewaczkę. Sprowadza się ono do odkrycia, że mowa nie jest wyrazem, ale więzieniem człowieka: ludzie są ofiarami słów²2.

${ }^{21}$ A. Brillant-Annequin, dz. cyt., s. 485.

${ }^{22}$ J. Błoński, Ionesco: genealogia stereotypu, „Dialog” 1967, nr 1, s. 80; por. też: O. Riewzina, I. Riewzin, Ionesco jako eksperyment semiotyczny, przeł. J. Faryno, „Dialog” 1973, nr 3, s. 74. 
I wyrażona nieco dalej uwaga - ważna dla przedstawionego tu omówienia Nosorożca - że ,język odzwierciedla odziedziczone przez jednostkę stosunki społeczne, nie zaś - tej jednostki jedyność i niepowtarzalność”23.

Po licznych odgłosach, wykrzykiwanych wyrażeniach dźwiękonaśladowczych (rykach, które na przykład Daisy wydają się w pewnym momencie melodyjnym śpiewem), po coraz głośniejszej galopadzie, gromkich tupotach, zwiastujących kolejne zwycięstwa „akcji bezpośredniej”, wymowna staje się na końcu cisza zapadająca na scenie. Bérenger został zupełnie sam pomiędzy nosorożcami. Tu warto zwrócić uwagę na rolę pauzy, milczenia, znaczącą nie tylko u Harolda Pintera, lecz także w dramatach Becketta i Ionesco, w tym przypadku - na ciszę, manifestującą niemożliwą komunikację między ludźmi.

Zanik biologicznej tożsamości ze światem ludzkim ${ }^{24}$ - zerwanie związków z tworzoną przez dzieje kulturą i cywilizacją oraz pielęgnowanymi w ich obrębie wyższymi wartościami - nastąpił, stał się faktem. Dzikie ryki, na razie przerażające, później wabiące ucho kolejnych członków przedstawionej w sztuce społeczności i zachęcające do przyłączenia się do silnego stada, przycichły, cel został osiągnięty. W obliczu takiej sytuacji można tylko milczeć.

Tak jak Bérenger ze sztuki Ionesco Morderca do wynajęcia nie potrafił przekonać zabójcy, że nie należy zabijać ludzi, tak jak w tamtym utworze nie odniosły pożądanego skutku jego wezwania, by grasujący zabójca „bez poborów” w ogarniętym strachem mieście (symbol super nowoczesnego, lecz bardzo niebezpiecznego świata) darował mu życie, tak i jego sympatyczny imiennik ponosi podobną klęskę w Nosorożcu. Nie może on bowiem powstrzymać „nosorożcowej” epidemii. Panująca w masie ignorancja, niemoc, niechęć do zmiany siebie lub innych sprawia, że samotne usiłowania szlachetnej jednostki kończą się fiaskiem. Przestrzeń, w której egzystuje bohater utworu, w sposób znaczący zawęża się. Bérenger natrafia na opór wszystkich poddających się stopniowo „akcji bezpośredniej”, także tych, na których mu szczególnie zależy, między innymi - swego przyjaciela Jana.

Bohater bezskutecznie odwołuje się do filozofii, której nie mają zwierzęta, do systemu wartości, budowanego przez całe wieki ludzkiej cywilizacji, do rangi kultury tworzonej przez istoty ludzkie. Na nic to się zdaje. Humanizm, do którego się odwołuje, zostaje przez przyjaciela nazwany „przestarzałym”, on sam zaś zostaje wyśmiany, nazwany naiwnym, ,śmiesznym, starym sentymentalistą”. Protagoni-

${ }^{23}$ J. Błoński, Ionesco: genealogia stereotypu, s. 80-81.

${ }^{24}$ Por. na ten temat trafne uwagi Małgorzaty Sugiery w książce Dramaturgia Stawomira Mrożka, Universitas, Kraków 1996, s. 19. Sygnalizując, że u Becketta postaci przypominają często biologiczne maszyny, badaczka pisze: „Ionesco podważa nawet to minimalne poczucie biologicznej tożsamości. Dowodzi tego nie tylko łatwość, z jaką w Nosorożcu wszystkie - prócz Bérengera - postacie przemieniają się w gruboskórne zwierzęta. Większość jego bohaterów żyje przecież w ciągłej niepewności co do tego, czy istnieje jakiś metafizyczny pewnik, który dałby im większe prawo być ludźmi niż żyrafami czy jakimiś drobnoustrojami”. 
sta jest bezradny wobec wygłaszanego przez Jana, a nowo nabytego poglądu, że będzie znacznie lepiej, gdy się to wszystko zburzy ${ }^{25}$.

Narzucone masie postawy i zachowania, zgodne z nowym wyglądem (jak należy sądzić, symbolizujące ideologię społeczną i polityczną, scalającą rozchwianą, bezkształtną dotąd zbiorowość) uzyskały w Nosorożcu parodyjne wykrzywienie, napawającą wstrętem deformację, zawierającą w sobie autorską, jednoznacznie negatywną ocenę. „Akcja bezpośrednia” zastosowana wobec rozproszonej, lecz podobnej sobie zbiorowości ludzkiej zakończyła się w tym dramacie całkowitym upodobnieniem członków masy, którzy w nowej, wspólnej, zapewniającej im ochronę skórze, będą bezwzględnie miażdżyć i tratować Innych.

Wymowa postaw, sytuacji oraz zjawisk poddanych alegoryzacji i symbolizacji w Nosorożcu Ionesco jest z całą pewnością ponadczasowa i uniwersalna. Mechanizmy stosowania ,akcji bezpośredniej” zostały przez autora sztuki bardzo dobrze podpatrzone i niezwykle interesująco przedstawione. Groza zjawisk i sytuacji ukazanych przez pisarza za pomocą zwierzęcej alegorii jest szczególnie znacząca w kontekście wydarzeń drugiej połowy dwudziestego wieku spoza sceny teatralnej, mianowicie, w kontekście przejawów i konsekwencji faszyzmu oraz komunizmu. Nie możemy bowiem zapomnieć, że:

pierwszym [...] impulsem dla Nosorożca stał się widok zwierzęcia, gruboskórnego i prymitywnego, który w latach trzydziestych zrósł się dla dramatopisarza na trwałe ze zwycięstwem faszyzmu w Rumunii ${ }^{26}$. Ionesco „zapomniał” o nim do chwili, kiedy po dwudziestu latach symbol powrócił z poprzednią siłą i ładunkiem przerażenia, uzyskując znaną nam postać ${ }^{27}$.

Pomimo plastycznego i bogatego w dźwięki, maski i projekcje teatralnego ujęcia tego wzbudzającego grozę, wręcz odrażającego obrazu i pomimo także indywidualnej klęski głównego bohatera jako osoby reprezentującej ufność w te wartości kultury humanistycznej, które miały dać odpór ,zezwięrzęceniu” ludzi, jesteśmy tu oto również świadkami jego indywidualnego zwycięstwa. Otóż

${ }^{25}$ Tu w sposób szczególny przypominają się znamienne mechanizmy oddziaływania ideologii faszystowskiej, drogi dochodzenia do nazizmu, a także literackie świadectwa kolejnych etapów tej drogi, np. dialog profesora Achima von Arnim ze swoim studentem, bohaterem powieści - apokryfu niemieckiego autorstwa Stanisława Grochowiaka pt. Trismus, w którym profesor wyśmiał „sentymentalne” ideały bohatera utworu, przyszłego architekta, wyjaśniając m.in., w jaki sposób znajomość arkanów architektury przyda się do burzenia starego porządku (S. Grochowiak, Trismus, w: tegoż, Prozy, wybór i oprac. J. Łukasiewicz, Atena, Warszawa 1996, s. 190).

${ }^{26}$ Trzeba zaznaczyć, że w Rumunii 1 marca 1938 r. ogłoszono nową konstytucję, rozwiązującą parlament i znoszącą swobody obywatelskie. Powstał faszystowski Front Odrodzenia Narodowego, nastąpiła stopniowa faszyzacja kraju i zacieśnienie stosunków z Niemcami hitlerowskimi, których interesom podporządkowano niemal wszystkie dziedziny państwa.

${ }^{27}$ A. Brillant-Annequin, dz. cyt., s. 487. 
bowiem Bérenger, „zwyczajny człowiek” i homo nobilis w jednej osobie znalazł w sobie siłę, by nie poddać się naciskom ,akcji bezpośredniej”. Tylko on nie uległ „nosorogaciźnie”, tylko on, jako jedyny z członków przedstawionej przez dramaturga zbiorowości, ujarzmił w sobie „lęk przed dotknięciem” - lęk przed bezlitosnym dotknięciem groźnej, napierającej zewsząd masy ${ }^{28}$.

W uwzględnionych tu prefiguracjach konfliktu: jednostka - społeczeństwo masowe wydaje się on obok Protagonisty z Katastrofy Becketta jedną z najbardziej wyrazistych postaci dramatu XX wieku, choć od heroicznej i tragicznej zarazem monumentalności bohatera Becketta odróżnia go swego rodzaju zwyczajność i bezradna wrażliwość osoby próbującej przeciwdziałać groźnemu rozwojowi wypadków, a potem z niepokojem i smutkiem obserwującej to, co się dzieje ${ }^{29}$.

Przykład Bérengera - bohatera Ionesco i wysuwane przezeń argumenty okazały się wprawdzie bezskuteczne w obliczu wydarzeń, lecz swą postawą wyraził on uczuciowy i moralny związek ze szlachetnymi wartościami etyczno-moralnymi kultury humanistycznej, zagłuszanymi najpierw w stereotypowej gadaninie, później w barbarzyńskim wrzasku - z wartościami, które zostały odrzucone, a później wręcz brutalnie podeptane przez masowo powiększające się stado ludzi-zwierząt.

Jak się okazuje, i tak jest od wieków, metoda „akcji bezpośredniej”, ta „Magna Charta” barbarzyństwa, jak ją określił Jose Ortega y Gasset, stosowana przez butnych i silnych, nie zawsze jest skuteczna. I to przesłanie czyni sztukę Eugène'a Ionesco prawdziwie uniwersalnym tekstem w swoistej „kosmologii” dramatu absurdu.

\section{Bibliografia}

\section{Podmiotowa}

Eugène Ionesco, Nosorożec, w: tegoż, Teatr, oprac. i przedmowa Marta Piwińska, t. II, Państwowy Instytut Wydawniczy, Warszawa 1967, s. 98-211.

\section{Przedmiotowa}

Błoński Jan, Od „Łysej śpiewaczki” do Bérengera, „Dialog” 1963, nr 3, s. 101-102.

Błoński Jan, Ionesco: genealogia stereotypu, „Dialog” 1967, nr 1, s. 80-81.

Brillant-Annequin Anick, Teatr absurdu: narodziny współczesnej estetyki. Na przykładzie dramaturgii Ionesco i Becketta, tłum. Małgorzata Sugiera, „Ruch Literacki” 1995, z. 4, s. 479-488. Kosiński Jan, ,Theatrum” Ionesco, „Dialog” 1963, nr 3, s. 96-98.

${ }^{28}$ Inaczej „lęk przed dotknięciem” ukazał w jednym ze swych dramatów Harold Pinter, akcentując narastanie tego lęku nie pod naciskiem brutalnej siły, lecz na skutek pozornie zwyczajnych (jakoby rutynowych) działań, podjętych, wobec bohatera; por. A. Wolska, Harold Pinter - „Urodziny Stanleya”: kiedy dotknięcie staje się wyrokiem, „Acta Universitatis Lodziensis. Folia Litteraria Polonica" 2003, t. 6, s. 405-423.

${ }^{29}$ Zob. A. Wolska, Metoda ,akcji bezpośredniej”" i strategie obronne bohatera dramatu ,Katastrofa” Samuela Becketta: sztuka dedykowana Vaclavowi Havlowi, „Prace Polonistyczne”, t. LIX: Tobie teraz. W kręgu literackich ofiarowań, Łódź 2004, s. 199-221. 
Nyczek Tadeusz, Havel: u szczytu schodów, „Dialog” 1990, nr 11, s. 90-92.

Ortega y Gasset Jose, Bunt mas i inne pisma socjologiczne, przeł. Piotr Niklewicz i Henryk Woźniakowski, wstęp Jerzy Szacki, Państwowe Wydawnictwo Naukowe, Warszawa 1982.

Riewzina Olga, Riewzin Izaak, Ionesco jako eksperyment semiotyczny, przeł. Jerzy Faryno, „Dialog" 1973, nr 3, s. 74-78.

Sugiera Małgorzata, Dramaturgia Sławomira Mrożka, Universitas, Kraków 1996.

\section{Anna Wolska}

\section{Animalization of the human world. Eugène Ionesco, Rhinoceros}

\section{(Summary)}

The article presents the originality and the timeless meaning of the 1959 Eugène Ionesco play, $R h i$ noceros which is situated, despite its unambiguous 'animal' parable, within the Theatre of the Absurd. In the perspective of the author of the article it is not only Ionesco's protest against fascism conditioned by the political circumstances which is significant in particular time but the work portraying mechanisms of influence on society, which appears as 'the masses', the whole of the society, devoid of any deeper connection with ethical and moral values of humanistic culture, common to all authoritarian ideologies. Among others, the article refers to opinions of scholars of drama and theatre critics on the evolution of Ionesco's dramatic works and such sociological-cultural and literary contexts as: 1) José Ortega y Gasset's thoughts on brutal 'direct action' applied to the masses by force factors and on 'fear of touch' felt by an individual defending the values of humanistic culture, included in The Revolt of the Masses; 2) plays by Ionesco in which the theme of metamorphosis is important; 3 ) other works of the Theatre of the Absurd of similar meaning but using different artistic means, Samuel Beckett's Catastrophe in particular.

Keywords: Twentieth Century Drama; the Theatre of the Absurd; Eugène Ionesco; Rhinoceros Słowa kluczowe: dramat XX wieku; dramat absurdu; Nosorożec Eugène'a Ionesco 